УДК-323

DOI: 10.17072/2218-1067-2020-4-5-13

\title{
FROM IDEOLOGY TO HATE SPEECH AND THE PROBLEM OF EURO-AMERICAN WHITE SUPREMACIST EXTREMISM
}

\author{
Gonzalez Cedillo, Joel Ivan \\ St.-Petersburg State University
}

\begin{abstract}
This article analyzes the relation between ignorance and extremism, and the proposed process, which transforms the ignorance into hate speech the elite uses to achieve their political goals. This type of analysis continues to become more urgent as fascism and ethnonationalism gain popularity in Western societies and in their politics. The article analyzes the definitions of ideology and ideological consistency presented by several academics to understand how extremist ideologies manage to get individuals engaged, and to propose a definition of ideology and extremism. The analysis of manifestos written by two American white supremacist terrorists, who in 2019 murdered twenty-three people in the US are included to demonstrate the relation between the lack of legislation for protecting freedom of speech, ignorance, and the commission of violent deadly attacks on innocents. The conclusion exposes the necessity of legislation that protects freedom of speech and a healthy social coexistence, as well as education and critical thinking skills to avoid the emergence of Euro-American white supremacist extremism. This theoretical and documental research might be used by academics working on ideology and political extremism in Western countries, as well as by policymakers trying to understand the phenomenon of white supremacist extremism.
\end{abstract}

Keywords: ideology; extremism; American white supremacism; racism; hate speech; Neo-Nazism; fascism; terrorism.

\section{Introduction}

With D. Trump's presidency of 2016 public expressions of support to the ideology of white supremacism in American and European societies have been normalized. D. Trump clearly did not start the white supremacist movement, but his public expressions as a candidate against ethnic minority groups, his proposition to build a wall at the border with Mexico, his position against immigration from Haiti, African and Muslim-majority countries and his desire for more immigrants from countries like Norway, empowered the discourse of existing white supremacist groups and leaders who protected by the $1^{\text {st }}$ Amendment started to publicly and more aggressively call for the elimination of non-Europeans in the US. The aim of this paper is to demonstrate the connection between what is said and sponsored by ideologues of Euro-American white supremacism with the actions taken by the audience attending their discourse, to propose the responsibility of the former in the actions of the latter, as well as to demonstrate the relevance of legislation that guarantees freedom of speech and social coexistence protecting the personalities of all individuals. This has become a needed analysis in the study of extremism since, as of 2019, white supremacists have killed more people in the US than Islamists after $9 / 11$ however, the focus of media and academia continues to be on the latter (Byman, 2019). How are white supremacist extremists influenced by hate speech to commit acts of terrorism? How to counter such hate speech to detach risk population from it? To answer these questions I will review the works of academics on ideology and hate speech to provide a theoretical framework. The methodology used is a content analysis of primary sources (manifestos) produced by American white supremacist terrorists Patrick Crusius (El Paso, August 2019) and John Earnest (Poway, April 2019).

\section{The Theoretical Evolution: From Ideology to Hate Speech}

The term "ideology" was coined in 1796 by Destutt de Tracy and was originally aimed at meaning "the science of ideas" or "the analysis of ideas" that described the liberty in the flux and direction of ideas the French people gained after the Revolution that ended the control of the elite on the destiny and behavior

(C) Gonzalez C. J. I., 2020 
of the masses (Kennedy, 1979:354-355). For the changes in society "ideology" demanded that contradicted the interests of Napoleon, ideologues were vilified and the term acquired a negative connotation that remains until today. However, relevant analyses of the term have been made that help understand "ideology" is more than a mere cluster of abstract thoughts.

Marxist philosopher A. Gramsci understood ideology from a class struggle approach in which, the imposition of ideas elaborated by an elite served as a tool of government control of the masses (Filippini \& Barr, 2017:8). Gramsci also claimed, individuals may align to a set of ideas they consider they can identify with, based on personal experience gained through social interaction (Filippini \& Barr, 2017:8). Gramsci identified two types of ideology: 1. Ideology as a science of ideas that "studies the formation of ideas on the basis of their derivation from sensations" and 2. Ideology as a set of ideas "that each person possesses, which does not depend on physiological causes but on historical-political ones" (Filippini \& Barr, 2017:7). Based on this, we understand ideology can be negative or artificial - if it is created and pushed by an elite on members of the society to serve as a tool of control and manipulation (dominant-dominated linear imposition of ideas) - and positive or natural - if born from social interaction without the influence of an elite group (circular exchange of experiences regardless of the status of the participant).

Unlike Tracy's proposition of ideology as a system of ideas, for Gramsci ideology was not limited to abstract thoughts in the minds of the elite or the individuals interacting as it required also emotions to give a meaning to those thoughts and make them capable of transforming communal reality. Ideologies target emotions as they provoke faster and sometimes irrational reactions on emotional individuals. If artificial ideology uses rational discursive elements rather than emotional, it becomes easy to destroy it with logical arguments in a counter propaganda strategy (Montgomery, 1999:453). Additionally, knowledge of the proper emotional context is needed for the artificial ideology to be efficient, i.e. anger or joyfulness might not be transmitted equally in societies with a different ethnohistorical background (Huaco, 1971:246).

J. Stanley proposes ideology is transmitted in two ways: through narrative (linear) and a process of enculturation (circular), matching the proposed above paradigm of transmission "negative-linear" and "positive-circular" (Protevi, 2016:360-361). Negative or artificial ideology is transmitted from a top-to-bottom narrative in which an elite decides the content of the ideology. Calling it "negative" ideology does not mean the set of ideas is negative or harmful for society or some of its members, it is negative because it is artificially created to control the masses from a privileged position in which dominated individuals have little chances to escape. As such, "negative" or artificial ideology can be intended to correct or dictate behavior from the perspective of the elite, i.e. patriotism, feminism, patriarchy, ethnonationalism, internationalism are all "negative" ideologies not because they may do harm but because they are artificially created.

On the other hand, calling "positive" ideology the set of ideas produced by social interaction and transmitted through a process of enculturation lies on the issue that individuals are free to produce and transmit their ideas free from the influence of a privileged group that tries to manipulate and control them. Examples of "positive" ideology are traditions, customs, art, worldview, culture and conclusively the national identity.

However, artificial ideology can lose its "negative" character if it successfully infiltrates into the psyche of individuals and starts being transmitted through enculturation or social interaction, i.e. patriotism may originate artificially through the selected elements the elite wants the society to have. Once society accepts these artificially created ideological elements, they will start to be transmitted as part of the national identity of such society.

Based on the previous analysis, ideology can be defined as a set of ideas that can either be constructed in the minds of individuals naturally through a process of enculturation or artificially through the psychological discursive practice. This set of ideas is not limited to cognitive concepts as it also must include emotions, necessary to give such concepts a meaning. The aim of natural ideology is to provide individuals with cognitive means to understand and transform their reality, while the aim of artificial ideology is to achieve gains (political, economic, social...) that serve the interests of an elite. In this regard, the psychological discursive practice of artificial ideology can present a distorted representation of reality to create a false consciousness.

The constant delivery of artificial ideology in the minds of vulnerable or ignorant individuals creates an ideological consistency. In his theory of political extremism, S. Lipset explains ideological consistency makes individuals more likely to choose a political extremist alternative than those who are ideologically inconsistent, as those who are ideologically consistent have "a simpler view of the world" (Smith, 2003:78). Such "simpler view of the world" is created through the lack of criticism individuals may otherwise receive if they allowed other ideological points of view that challenged those of their own ideological consistency. 
When individuals are deeply immerse in their ideological consistency, they end up creating an individualized Truth. These individuals will later become sectarian when they meet others that have been also victims of the same artificial ideology and who have also formed the same ideological consistency. The Truth is sectarian because, its defenders will view themselves as exclusive and clearly differentiated from "the others" (Baker, 2018:2). To understand the concept of the Truth, N. Kazinsky explains "outside the Truth, there is no Truth, outside of roundness there is no circle, outside of a person there is no person. There is no Truth other than the Truth, neither outside of it, nor in anything else" (Yakupov, 2009:575). The previous means that, as Reality the Truth is also subjective, and its conception depends on the position of the observer. As a result, individuals become extremists when they work to impose their sectarian Truth on others of whom they do not acknowledged or respected their Truth (Baker, 2018:7). Extremism can then be understood as the imposition of the individual or sectarian Truth on others that itself is the result of artificial ideology.

The imposition of the individual or sectarian Truth requires a discourse that humiliates or dehumanizes those individuals who do not accept this Truth. Such humiliation and dehumanization of the other may already be elements of the artificial ideology or they can also be incorporated after the artificial ideology is accepted by vulnerable individuals. The artificial ideology will create or use existing fears and negative emotions toward "the other", exploit the "us vs them" narrative and use social categorization strategies (Tajfel, 1982:20-23) to target individuals they want to convert into the undesired. This discourse, also known as "hate speech", is used as a rhetorical attack against the considered protected characteristics of individuals like gender, sex, ethnicity, religion, national origin or race (Hate speech vs. free speech: what are the UK laws?, 2018). However, hate speech is a term that has no legal definition in many Western countries, and in the case of the United States, hate speech is protected by the Constitution. This constitutional protection allows negative or artificial ideologies to spread, attack or call for violence against sectors of the population they consider to be inferior.

To P. Riordan, the American perception of freedom of speech originates in freedom of expression (covering freedom of the press) and was originally intended to protect citizens against state censorship and to function as a tool of democracy against tyrannical European models of the XVIII c. The advent of social media and the following empowerment of individuals of all ideological spheres, Riordan questions if it is modern society and not the government that can limit freedom of speech by social coercion to end up becoming a factual tyranny of the majority (Riordan, 2016:159-160).

Riordan argues that limits on freedom of speech are permitted in certain contexts if they are supposed to prevent violence, as the main goal of such freedom must be to promote peaceful coexistence in society, advance wisdom and put the "official" government discourse under examination using rationality by facilitating an "open and lively debate of opposing points of view" (Riordan, 2016:160-163. The exercise of the right to a free speech has to always take into consideration the dignity and recognition of other members of society, as Riordan argues, this right was not intended to be an unchecked speech full of hatred directed at other citizens' dignity (Riordan, 2016:162-167).

Nevertheless, in the 1970's, the US Supreme Court deemed hate speech was protected under the constitution changing the original conception of this right (Riordan, 2016:163), de facto eliminating the call for intelligent debate and criticism of tyrannical systems, transforming it into an ultra-individualized right. This American perception has been a fertile ground for white supremacists and Neo-Nazism, unlike in most European countries where sanctions exist on hate speech (Riordan, 2016:165).

Others like C. Nelson see the right to free speech as an absolute right that can and must trample the dignity of others to ironically guarantee the protection of such freedom (Nelson, 1997:119), as in his understanding, allowing the government to dictate what is undesirable speech risks the continuation of democracy. Nelson proposes the solution to hate speech, thought long term, is more speech that challenges the initial racist, sexist or homophobic offenses, and in which authorities must not intervene to punish the perpetrator, claiming social pressure like harassing the speaker of hatred is more efficient at ending the problem than legislation (Nelson, 1997:118).

S. Neshkovska and Z. Trajkova define hate speech as "the hateful, demeaning and dehumanizing messages against particular individuals, or groups of individuals on the grounds of their political affiliation, religious conviction, ethnicity, sexual orientation, disability, etc." (Neshkovska \& Trajkova, 2017:71) which is a useful definition to understand this concept regardless of cultural or historical aspects of the society trying to define it. They classify hate speech in three stages based on its intensity: 1. Soft: Statements that create a negative image of a group or individual, 2. Moderate: justifies historical violence and discrimination 
against one group, 3. Harsh: explicit calls for violence and discrimination (Neshkovska \& Trajkova, 2017:73).

Neshkovska and Trajkova question whether or not hate speech should be considered free speech, as to them, the former has the potential to be destructive as they claim, some people hide under the protection to free speech to humiliate and dehumanize other individuals (Neshkovska \& Trajkova, 2017:77-79). In their analysis they include a middle position to legally approach hate speech, contradicting what the other authors used for this work defend as an absolute right. This position is against the government extremely censoring all speech challenging the dominant discourse but also approves the punishment of any hateful expressions targeting race, gender, religion, ethnic origin, sexual orientation (Neshkovska \& Trajkova, 2017:71). These academics identify hate speech is successful in societies polarized by religion, politics and ethnicity and claim it "appears whenever someone needs the urge to demean or demonize" the other, especially during political elections (Neshkovska \& Trajkova, 2017:72-74).

With the above we understand hate speech is rooted in the acceptance of the individual - later sectarian - Truth as unique, which can be tracked to the work of the ideologue in creating an ideological consistency founded on ignorance among the dominated. Hence, ignorance is the root of hate speech and thus, extremism (Gonsales, 2019a:7). The elites or the dominant actors in society can also be speakers of hatred whose source is not ignorance, but rather the necessity to manipulate the masses for political gains. Ignorance is the source of extremism because it is through an ideological consistency that the individual is convinced a fabricated Truth is and must be universal.

\section{Euro-American White Supremacist Extremism}

White supremacism is the artificial ideology that claims non-Europeans, especially "non-Aryans", are inferior and is founded on the pseudo-scientific movement of the XIX c. born in Europe known as eugenics, that later popularized among some sectors of the US society (Gonzalez, 2019b:116). Some reasons eugenics and white supremacism were able to resonate in the US were, among others, religion (Calvinist predestination) and the strong religiosity of some Americans that favors the rejection of science over religion ( $42 \%$ believe in creationism, 31\% believe humans evolved with the guidance of God as of 2014) (Newport, 2014), history as a country that benefited from slavery of Africans and further segregation of AfricanAmerican citizens up until the XX c., as well as the mass murder of Native Americans during the European colonization and expansion to the West Coast.

The political discourse fabricated by S. Bannon, and to a lesser extent S. Miller, Trump's ideologues, in 2015 that targeted minorities served as ideological inspiration for the far-right and some white supremacists, among them Patrick Crusius who in 2019 committed a terrorist attack in El Paso to, as he claimed after his arrest, kill as many Mexicans as possible. This political discourse targeted Mexicans and presented them as a threat for American security. Among white supremacists it is also believed Mexicans and Latinos are a threat for the existence of European ethnicity in the US. In his inaugural discourse as presidential candidate in 2015, D. Trump referred to Mexicans saying: “They're bringing drugs. They're bringing crime. They're rapists. And some, I assume, are good people", a month later he claimed "The Mexican Government is forcing their most unwanted people into the United States. They are, in many cases, criminals, drug dealers, rapists, etc." (Ye Hee Lee, 2015). This is the ideological anti-immigrant discourse Crusius was exposed to that created the ideological consistency that moved him to commit his actions.

Prominent American politicians, including the President, as well as media hosts at Fox News ignited ethnic tensions against Central American immigrants (not illegal in the US) several times by claiming migrants from Honduras, Guatemala and El Salvador were "invading" the US through the Southern border during the immigration crisis of 2018-2019, it is documented some hosts even suggested the US Army must intervene to stop such "invasion" (Mackey, 2019). Such claims are protected by the $1^{\text {st }}$ amendment of the US Constitution guaranteeing freedom of speech. The two cases of white supremacist terrorists analyzed here expose how the authors used their freedom of speech to challenge the current social and political discourse on the multicultural composition of the US and try to promote an ethnonationalist and fascist solution what they perceive is the forced extinction of Aryans.

After months of continuous anti-immigrant propaganda on media and political discourses, Crusius armed himself with a WASR-10 (a semiautomatic AK-47 rifle) and headed to El Paso, a Texan city right at the border with Mexico where the majority of the population is of Mexican origin. This terrorist wrote a four pages manifesto titled "The Inconvenient Truth" he posted online and then murdered twenty two people. Though it could be questioned if Crusius terrorist acts are the direct result of the exposure to the political 
discourse that presents Mexicans and immigrants as a security threat to the US, the fact is that as a resident of Dallas, he took a weapon and drove one thousand kilometers to the US-Mexico border with the intention to kill and stop "the invasion" he understood was taking place. Crusius' manifesto shows he was being exposed to months of political propaganda in media as the Central American migrant caravans approached the US-Mexico border. On the other hand, B. Tarrant served as an operational inspiration for Crusius: he also wrote a manifesto explaining his actions, armed himself and drove to hit his target. Tarrant is not an ideological source for Crusius, as the former targets Muslims and non-Europeans, while the latter targeted Mexicans and Latinos who are considered a multi-ethnic group, that includes those of European or mestizo origin.

Crusius' manifesto is divided into the sections about me, political reasons, economic reasons, reaction, personal reasons and thoughts, gear. In the manifesto the perpetrator claims "The Natives didn't take the invasion of Europeans seriously, and now what's left is just a shadow of what was" clearly referring to the European invasion and colonization of North America in the XVI c and the perceived inaction of Native Americans (Crusius, 2019:1). Crusius claims that "the Democrat Party will own America and they know it...They intend to use open borders, free healthcare for illegals, citizenship and more to enact a political coup by importing and the legalizing millions of new voters" (Crusius, 2019:1).

Crusius makes an interesting statement: "Our European comrades don't have the gun rights needed to repel the millions of invaders that plaque their country." making reference to a similar refugee crisis that happened in the EU in 2015, the necessity he sees Europeans have to exterminate "the other" and the lack of gun rights in Europe that Americans do have (Crusius, 2019:3). This white supremacist also calls multiethnic couples "race mixers" stating:

I am against race mixing because it destroys genetic diversity and creates identity problems...Cultural diversity diminishes as stronger and/or more appealing cultures overtake weaker and/or undesirable ones. Racial diversity will disappear as either race mixing or genocide will take place. The best solution for this for now would be to divide America into a confederacy of territories with at least 1 territory for each race. This physical separation would nearly eliminate race mixing and improve social unity by granting each race self-determination within their respective territory(s) (Crusius, 2019:4).

As final remarks he claims "My ideology has not changed for several years. My opinions on automation, immigration and the rest predate Trump and his campaign for president" and "This is just the beginning of the fight for America and Europe. I am honored to head the fight to reclaim my country from destruction" (Crusius, 2019:4).

The Jewish community is also a target of Euro-American white supremacists and Neo-Nazis, who in the summer of 2017 held torches and marched the streets of Charlottesville, Virginia chanting "Jews will not replace us!" inspired by conspiracy theories that denounce Jews sponsor Islamization and mass-immigration of non-Europeans into the US and Europe (Wong et al., 2015:45). In October 2018, a white supremacist terrorist killed 11 people at a Synagogue in Pittsburgh, Massachusetts in what has been the deadliest attack on the Jewish community in US soil. In December 29, 2019 a white supremacist terrorist killed a rabbi and wounded five other people attending a Hanukkah celebration in New York City. Inspired operationally and ideologically by Tarrant's attack, white supremacist John Earnest killed one person and wounded three other in a shooting at Poway Synagogue on April 27, 2019 in San Diego, California. Earnest wrote a manifesto titled "An Open Letter" containing nineteen questions and answers where he explains his motives and ideology.

Earnest's manifesto freely claims "I would die a thousand times to prevent the doomed fate that the Jews have planned for my race" and "Every Jews is responsible for the meticulously planned genocide of the European race" (Earnest, 2019). Immersed in his ideological consistency based on a form of religious Christian extremism he blames Jews for the following:

Their crimes are endless. For lying and deceiving the public through their exorbitant role in news media; for using usury and banks to enslave nations in debts and control all finances for the purpose of funding evil; for their role in starting wars on a foundation of lies which have costed millions of lives throughout history; for their role in cultural Marxism and communism; for pushing degenerate propaganda in the form of entertainment; for their role in feminism which has enslaved women in sin; for causing many to fall into sin with their role in peddling pornography; for their role in voting for and funding politicians and organizations who use mass immigration to displace the European race; for their large role in every slave trade for the past two-thousand years; for promoting race mixing; for their cruel and bloody history of genocidal behavior; for their persecution of Christians of old, members of the early church, Christians of modern-day 
Syria and Palestine, and Christians in White nations...And finally, for their role in the murder of the Son of Man - that is the Christ. Every Jew young and old has contributed to these. For these crimes they deserve nothing but hell. I will send them there. (Earnest, 2019).

Earnest claims his crime is part of a revolution of ethnic Europeans consisting of 1) ideologues, 2) fighters (defenders of the race) and 3) breeders (those who have children) and positions himself as a fighter ready to kill Jews and inspire others to follow him (Earnest, 2019). Earnest uses Christianity to justify his actions by claiming:

My God does not take kindly to the destruction of His creation. Especially one of the most beautiful, intelligent and innovative races that He has created. Least of all at the hands of one of the most ugly, sinful, deceitful, cursed, and corrupt. (Earnest, 2019).

By "one the most beautiful, intelligent and innovative races" he means whites or European Aryans and by "the most ugly, sinful, deceitful, cursed, and corrupt" he means Jews. He quotes verses from the Bible that justify his hatred of Jews like Matthew 27:24-25, 1 Thessalonians 2:14-16, Revelation 2:9 and Revelation 3:9. Earnest mentions he received funding from an individual called Felix Arvid Ulf Kjellberg and then confesses he set a mosque on fire a week after the Australian white supremacist terrorist B. Tarrant murdered people at two mosques in Christchurch, New Zealand.

One of the questions in the manifesto states "Are you affiliated with any political ideology?" to what Earnest answers "Yes. It's called not wanting to go extinct." meaning he feels an imaginary connection with every European-American or Aryan he believes is currently under threat by immigration of non-whites (Earnest, 2019).

This terrorist claims he does not feel any remorse, wishes to have killed more Jews and comments: "I hate anyone who seeks the destruction of my race. Every Jew currently alive plays a part in the destruction of my race.", this quote exposes the ideological consistency he believes in that was created by conspiracy theories like the Great Replacement (Earnest, 2019). To the question "Who inspires you?" he answered "Jesus Christ, the Apostle Paul, Martin Luther, Adolf Hitler, Robert Bowers, Brenton Tarrant, Ludwig van Beethoven, Moon Man and Pink Guy" - and then makes a call to Christians "of all races" to look for salvation by fighting Satan which to him is represented by Jews (Earnest, 2019). He gives a message to Jews "Your crimes - innumerable. Your deeds - unacceptable. Your lies - everywhere. The European man will rise up and strike your squalid and parasitic race into the dust. And this time there will be nowhere for you to run." (Earnest, 2019).

Earnest as Crusius found operational inspiration in B. Tarrant's attack, who at the same time was inspired by Anders Breivik, the Norwegian white supremacist terrorist who in July 2011 killed seventy seven people in Oslo and Utoya, Norway. Breivik has become a reference, not an ideological source, for white supremacist terrorists to write manifestos like the one he wrote and titled "2083: A European Declaration of Independence", that by itself, contains references of American voicers of the far-right, as well as expressions that demonstrate the use of Christianity as an ideological justification for his hatred toward Muslims. Tarrant does share Breivik's ideology, but Crusius and Earnest are different, the former targeted Mexicans and Latino immigrants, while the latter focused on Jews. Crusius was ideologized by the anti-immigrant political discourse he was exposed. Earnest confirms his ideological inspiration was Tarrant, but definitely he was exposed to other white supremacist extremist sources as Tarrant does not focus on Jews as Earnest does.

\section{Conclusion}

Euro-American white supremacist extremism has become a serious threat for social coexistence in the European continent, Australia, New Zealand, the US and Canada, equally toxic and dangerous as Islamism. Unlike the latter, white supremacists enjoy the protection of their ideology under the umbrella of free speech in the West, with some of its promoters getting podiums in universities, TV or political platforms to run for public positions. This is specially prominent in the US where such supremacist discourse is protected speech by the first Amendment. Social media initially played an incredible role in the mass spread of EuroAmerican white supremacist extremism allowing content to be shared like videos, pictures, memes, stories, symbols and conspiracy theories, until platforms like Facebook, YouTube and Twitter started receiving pressure from governments and society to filter such content and eventually ban it. However, there are still some profiles that manage to spread such content as a political alternative to progressive and inclusive policies. There are still politicians and political parties in Western countries that use hate speech to instigate fear and get votes, a strategy that contributes to a cycle of extremism in which one side (white supremacism) feeds the other (Islamists). 
The above is the direct result of a lack of legislation that protects actual freedom of speech and the rights of other citizens to a safe life and the free development of their personality. The American approach to freedom of expression was born out of a legitimate necessity to provide citizens with the tools to prevent tyranny and despotism from the authorities, however, this interpretation was dropped and the resulting absolutism of this right and its distortion into the freedom to offend is the result of an ultra-individualized and wild capitalist evolution of their society that obeys historical and societal particularities.

Extremism and hate speech are usually linked by ignorance the individual espousing such ideas owns, though not all speakers of hatred are moved by ignorance but rather by their desire for power. Ignorance is such link because, as suggested by the theoretical analysis of ideology and ideological consistency presented in this work, when individuals are convinced the artificial ideology they accepted represents the Truth they are no longer willing to accept other versions of the same issue and end up becoming extremists. The solution to break an ideological consistency must be educating individuals with critical thinking skills to help them differentiate how an artificial ideology and a fabricated Truth can wrap them into believing a set of ideas that only benefit an elite like politicians or mass media outlets. Crusius' extremism is based on ignorance of economic and social issues of his own country, as he blames the lack of opportunities for ethnic European Americans on Mexican immigrants, rather than the economic and political system that makes it expensive to get quality university education for average Americans. The loss of jobs of the unskilled is also an issue Americans like Crusius worry about and choose to blame immigrants, rather than advent of automation and the maximization of capital by the economic system itself. Similarly, Earnest blames Jews for issues like Marxism, wars, public debt and slavery, among other, rather than understanding these are the results of capitalist systems that need to continue to operate at the expense of the exploitation of individuals.

Ideologues with access to resources and interests in political gains will take advantage of the ignorance on political, economical, historical or social issues to produce ideologies that become fabricated Truths ignorant individuals will accept as universal. Teaching and reinforcing critical thinking skills, as well as scientific methodology must be a necessity from early stages of education but also for grown adults who are also easy victims of extremist propaganda on social media similar to what Crusius and Earnest were exposed to. This is a task that must be relevant for the State to avoid the circulation of toxic ideas and movements that undermine social coexistence as it is the ideology of white supremacism and fascism. Education must also be accompanied by legislation that persecutes the use of discourse aimed at starting conflicts based on gender, religion, ethnicity or any other considered protected characteristics of the individual.

\section{References}

Гонсалес Седилло, Х. И. (2019а) 'Роль мусульманской уммы в борьбе с Ваххабизмом как политическим движением в России и Германии', Исламоведение, 10(1), cc. 5-16. [Gonsales Sedillo, H. I. (2019a) 'The role of Wahhabism in the Fight against Wahhabism as a Political Movement in Russia and Germany' [Rol' musul'manskoj ummy v bor'be s Vaxxabizmom kak politicheskim dvizheniem v Rossii i Germanii], Islamic Studies, 10(1), pp. 5-16. (In Russ.)], DOI: 10.21779/2077-8155-2019-10-1-5-16.

Якупов, М. Т. (2009) 'Современный джихад (социально-философский анализ)', Вестник Башкирского Университета, 14(2), cc. 575-579. [Yakupov, M. T. (2009) 'Contemporary Jihad (A socialphilosophical analysis)' [Sovremennij dzhixad (sotsial'no-filosofskij analiz)], Journal of Bashkir University, 14(2), pp. 575-579 (In Russ.)].
Baker, J. (2018) 'Christian Sectarianism, Fundamentalism, and Extremism', in Routledge Handbook of Deviance. New York: Routledge, pp. 187-198.

Byman, D. (2019) 'Right-Wingers Are America's Deadliest Terrorists', Slate [online]. Available at: URL: https://slate.com/newsand-politics/2019/08/right-wing-terroristkillings-government-focus-jihadis-islamicradicalism.html (Accessed: 09.08.2019).

Crusius, P. (2019) The Inconvenient Truth [online]. Available at: URL: https://www.grandsupremenews.net/usnews-1/patrick-crusius-el-paso-texasshooters-manifesto (Accessed: 28.08.2019).

Earnest, J. (2019) An Open Letter [online]. Available at: URL: https:/edailybuzz.com/2019/04/28/johnearnest-manifesto/ (Accessed: 28.08.2019).

Filippini, M., \& Barr, P. (2017) 'Ideology. In Using Gramsci: A New Approach', Pluto Press, pp. 4-23. 
Gonzalez Cedillo, J. I. (2019b) 'Extremist Discourse: A Comparison Between Jihadi and White Supremacist Online Materials', Journal of Moscow Regional State University Series: History and Political Science, 3, pp. 115-123, DOI: 10.18384/2310-676X-2019-3-115-123.

(2018) 'Hate speech vs. free speech: what are the UK laws?', The Week [online]. Available at:URL:https://www.theweek.co.uk/9755 2/hate-speech-vs-free-speech-what-arethe-uk-laws (Accessed: 23.08.2019).

Huaco, G. (1971) 'On Ideology', Acta Sociologica, 14(4), pp. 245-255.

Kennedy, E. (1979) 'Ideology' from Destutt De Tracy to Marx', Journal of the History of Ideas, 40(3), pp. 353-368, DOI: $10.2307 / 2709242$.

Mackey, R. (2019) 'Donald Trump and Fox News Warned of a Migrant "Invasion" Before El Paso Gunman Struck', The Intercept [online]. Available at: URL: https://theintercept.com/2019/08/05/elpaso-gunmans-fear-migrant-invasionechoed-donald-trump-fox-news/ (Accessed: 29.08.2019).

Montgomery, M. (1999) 'On Ideology', Discourse \& Society, 10(3), pp. 451-454.

Nelson, C. (1997) 'Hate Speech And Political Correctness', in Manifesto Of A Tenured Radical. New York: New York University Press, pp. 115-125.

Neshkovska, S., Trajkova, Z. (2017) 'The Essentials Of Hate Speech', International Journal Of Education Teacher, 7(14), pp. 7180, DOI:10.20544/teacher.14.10.
Newport, F. (2014) 'In U.S., 42\% Believe Creationist View of Human Origins', Gallup [online]. Available at: URL: https://news.gallup.com/poll/170822/belie ve-creationist-view-human-origins.aspx (Accessed: 29.08.2019).

Protevi, J. (2016) 'Stanley on Ideology', Theoria: An International Journal for Theory, History and Foundations of Science, 31(3), pp. 357-369, DOI:10.1387/theoria.16326.

Riordan, P. (2016) 'Freedom of Expression, No Matter What?', Studies: An Irish Quarterly Review, 105(418), pp. 159-168.

Smith, R. (2003) 'Political Extremism: Left, Center, and Right', The American Sociologist, 34(1), pp. 70-80.

Tajfel, H. (1982) 'Social identity and social comparison. Social Psychology of Intergroup Relations', Annual Review Psychological. England: University of Bristol, pp. 1-39.

Wong, M., Frank R., \& Allsup, R. (2015) 'The supremacy of online white supremacists an analysis of online discussions by white supremacists', Information \& Communications Technology Law, 24(1), pp. 4173,DOI:10.1080/13600834.2015.101184.

Ye Hee Lee, M. (2015) 'Donald Trump's false comments connecting Mexican immigrants and crime', The Washington Post [online]. Available at: URL: https://www.washingtonpost.com/news/fa ct-checker/wp/2015/07/08/donald-trumpsfalse-comments-connecting-mexicanimmigrants-and-crime/ (Accessed: 23.04.2020).

\section{Информация об авторе}

Гонсалес Седилло Хоел Иван - исследователь / учитель-исследователь, Санкт-Петербургский государственный университет. E-mail: ivangzz.ced@gmail.com (ORCID: 0000-0001-8040-749X. ResearcherID: D-5975-2019).

Статья принята к печати: 30.10.2020 


\title{
ОТ ИДЕОЛОГИИ К НЕНАВИСТНИЧЕСКИМ ВЫСКАЗЫВАНИЯМ И ПРОБЛЕМА ЕВРО-АМЕРИКАНСКОГО БЕЛОГО СУПРЕМАСИСТСКОГО ЭКСТРЕМИЗМА
}

\author{
Седилло Хоел Иван Гонсалес \\ Санкт-Петербургский государственный университет
}

\begin{abstract}
Аннотация
Анализируется связь между невежеством и экстремизмом и предлагаемый процесс, посредством которого невежество превращается в ненавистнические высказывания, который элита использует для достижения своих политических целей. Этот тип анализа продолжает интенсивно расти, так как фашизм и этнонационализм набирают популярность в западных обществах, в политике и в обществе. Рассматриваются определения идеологии и идеологической согласованности некоторых ученых, чтобы понять, как экстремистским идеологиям удается вовлечь индивидуумов и предложить определение идеологии и экстремизма. Анализируется два манифеста, написанные двумя американскими террористами-белыми супремасистами, которые в 2019 г. убили двадцать три человека с целью продемонстрировать связь между отсутствием законодательства для защиты свободы слова, невежеством и совершением насильственных смертоносных нападений на невинных людей. В заключении раскрывается необходимость законодательства, которое защищает свободу слова и здоровое социальное сосуществование, а также навыки образования и критического мышления, чтобы избежать появления евро-американского белого супремасистского экстремизма. Это теоретическое и документальное исследование может быть использовано учеными, работающими над идеологией и политическим экстремизмом в западных странах, а также политиками, пытающимися понять феномен экстремистского белого супремасизма.
\end{abstract}

Ключевые слова: идеология; экстремизм; американский белый супремасизм; расизм; ненавистнические высказывания; неонацизм; фашизм; терроризм. 